\title{
THE TOURISM POTENTIAL OF THE NORTH CAUCASUS: THE FORMATION, CHARACTERISTICS AND DEVELOPMENT PROSPECTS
}

\author{
Svetlana ANDREYANOVA* \\ Stavropol State Agrarian University, Department of Tourism and Service, 355017, 12, \\ Russia, Stavropol, Zootekhnichesky Ave, e-mail: geoversum4ik@yandex.ru \\ Anna IVOLGA \\ Stavropol State Agrarian University, Department of Tourism and Service, 355017, 12, \\ Russia, Stavropol, Zootekhnichesky Ave, e-mail: annya_iv@mail.ru
}

\begin{abstract}
Citation: ANDREYANOVA, S., \& IVOLGA A. (2018). THE TOURISM POTENTIAL OF THE NORTH CAUCASUS: THE FORMATION, CHARACTERISTICS AND DEVELOPMENT PROSPECTS. GeoJournal of Tourism and Geosites. 22(2), 347-358. https://doi.org/10.30892/gtg.22206-293
\end{abstract}

\begin{abstract}
This research looks at the North Caucasus region at the south of Russia, a bridge between the Black and the Caspian Seas, its unique geographical location that determined the diversity of natural, climate and ethnographic resources. The goal is to show the modern complications concerning of the North Caucasus Region unique offer on the world tourist market. This has been done by examining different zones of nature management with their features in region. For this research we used coefficients relate with the social and economic development, and tourism attractiveness. As a result, we found the existing problems which lead to low internal demand and adverse demand on the international tourist market. Through showing that the Solving these urgent problems together with implementation of the Development Strategies will make the North Caucasus an attractive resort for different kind of tourists. This information will likely impact the design of future special tourist zones in the region.
\end{abstract}

Key words: tourism, geographical region, tourism development, North Caucasus

$$
* * * * * *
$$

\section{INTRODUCTION}

The North Caucasus is a geographical area (a part of Caucasus geographical region) located in the south of Russia between the Black and the Caspian Seas. Its conventional boundary passes across the Kuma-Manych Depression that had connected these seas in ancient times. The southern boundary passes along the summits of the Greater Caucasus and separates the territories of Georgia, the Republic of Abkhazia, the Republic of South Ossetia and the Republic of Azerbaijan (Figure 1). As for

\footnotetext{
* Corresponding author
} 
administrative and territorial division, the area is split into 9 regions. These include both Russian-speaking entities formed by Cossacks either voluntarily settled or exiled to this territory and national republics, where mostly indigenous Caucasian people live.

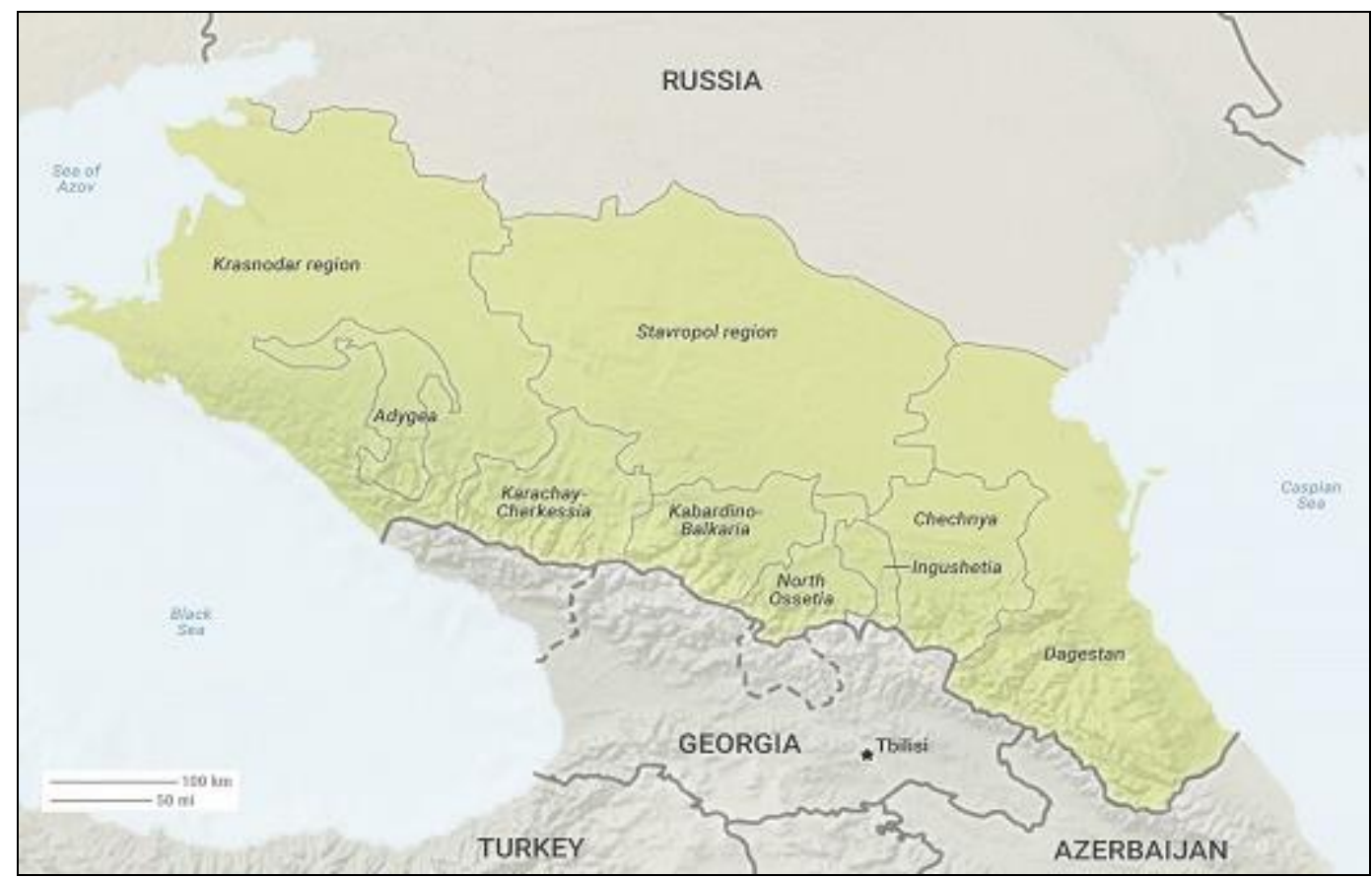

Figure 1. The map of geographical location of the study area (Source: GPF - Geopolitical Futures, (2017), https://geopoliticalfutures.com/north-caucasus-russias-southern-buffer/_2017)

Nowadays Russia possesses 258,3 thousand $\mathrm{km}^{2}$ of the North Caucasus area $(1,5 \%$ of the whole territory). This is one of the most rich recreation areas of the country. The diversity of natural, climate, balneological, ethnographic and other tourist resources promotes development of various types of tourism (Aleksandrov et al., 2015). Since ancient times, this region have been attracting the interest of different states and civilizations. Several directions of the Great Silk Route passed across this area. It was also a place of numerous grave mounds and burial grounds that contained unique artifacts. Megalithic ruins as ancient as Stonehenge were found there. Numerous migrations over the centuries made the ethnic map of the region on of the most confusing in the world. Only the Balkan Peninsula situated at the interface between Islamic and Christian civilizations can be considered as an analogue. Before studying the tourist heritage and existing modern tourist destinations of the region it is necessary to describe the administrative entities comprising it. This inductive approach (starting from the particular features of the regions before going to its general description) we let us to make the judgements on the current condition of tourist industry and prospects for the further development in conclusion.

Stavropol Krai. In the late $18^{\text {th }}$ century the main part of the southern border of the Russian Empire - the Azov-Mozdok defense line was constructed there. The settlements of Volga and Khopyor Cossacks were established in the border areas. At the same time in the east the Kuma river valley was occupied by the Nogai tribes, Turkic-speaking people, whose main occupation was distant-pasture cattle tending. Geographic location of Stavropol Krai determined the diversity of landscape and geographical belts - from the 
Stavropol highland and Strizhhament mountain in the west (max. $850 \mathrm{~m}$ ) to the TerekKuma lowland in the east (less than $100 \mathrm{~m}$ ). This difference in altitude leads to diversity of climate zones and floral belts - starting from the mild one to the semi desert. In the south of the region, where the shoots of the Caucasus begins locates the most famous Russian balneotherapeutic health resort - Caucasian Spas (Polyakova, 2015).

Thus, the area of the region can be provisionally divided into three zones:

1. the west - the regional center Stavropol city is located there. It can offer a big variety of architectural monuments. There are also thermal springs in the neighborhood of Kazminka village, a number of farms and guesthouses designed mainly for weekend break of Stavropol dwellers.

2. the south - where the health resort of Caucasian Spas with well developed net of medical and recreational centers is situated. There are also many places related to worldrenowned Russian poets. The unique geological features of this area provide a certain level of so-called medicinal radiation emanated from Beschtaunite magmatic rock. That is the factor that gives the local climate special medicinal features.

3. the east is an area of nomadic Nogai peoples and traditional wine production in the Kuma river valley. Currently the viticulture traditions are revived due to the famous brandy producer in Praskoveya. There lives a unique ethnic community of Nekrasov Cossacks returned to Russia from Turkey in 1960s. Nowadays there is an ethnic and cultural complex of Nekrasov Cossacks.

It is interesting to mention that the total area of Stavropol Krai is bigger than the one of the Netherland. Considering rather vivid ethnic composition, one can see the wide range of tourist resources. All these factors create strong potential for tourism development. Krasnodar Krai. Throughout history, this territory belonged to indigeneous Cherkes people and their ancestors - the Zygians, the Cercetae, the Maeotians, the Shapsugs and others. After expansion of Russia to this area it became home for the Kuban Cossack Host named after the Kuban River, the main waterway of this region. The references to the Kuban River can be found in writings of the Scythians, the Sarmatians, the early Slavs, the Greeks and the Romans.

The region has a vast coastline along the Black Sea. That results in the diversity of climate zones - from temperate one to subtropics. Uniqueness of regional climate is one of the reasons of the developed viticulture in this area of the North Caucasus. Nowadays Krasnodar Krai offers tourists the largest number of wine routes in Russia. Currently the wine map of the area consists of 14 wine route, each of which includes different activities: training workshops, degustation and winemaking. The other important feature of this area is unique archeological and cultural heritage - dolmen megalithic monuments at the coast of the Black Sea. Together with the natural heritage they create huge variety of cultural and ecological routes. It is obvious that access to the sea and prolific climate made this region the most popular one among the Russians for having beach-related rest. The center of Winter Olympic Games 2014, Sochi city region is also located in the region. The infrastructure facilities constructed for the Games attract additional tourist flows to Rosa Khutor ski resort and extreme park, seaside complexes in Adler and Central Sochi (Too, 2014). The Republic of Adygeya. Until fairly recently this region was an area of a single folk located inside Krasnodar Krai. The native people there are the Circassians including the Adyghe people. Provisionally the area of the region can be divided into three types: lowlands, piedmont plain and highlands. The last one is occupied with the LagoNaki plateau by $90 \%$. The latter is famous for its alpine meadows and numerous hiking routs developed back in the 1920-s. One of the most popular routs is the Route № 30 - as a family route of low difficulty level to the seaside through the mountains. Its duration varies from 20 to 5 days depending on the passes and pathways chosen. 
Uniqueness of natural heritage of the plateau creates microclimate of highland Switzerland in some of its parts. Mountain rivers with pure mineral water and beautiful landscapes become a perfect base for heath tourism. The region is also popular for water tourism organized on the Belaya river, the main Republic's waterway. Teams from America, Africa, Western Europe and Russia arrive to Adygeya annually to take part in rafting, catamaran and kayaking competitions (Shadova, Tappaskhanova, Abrhám, Zumakulova, 2015). At the same time event tourism gain popularity. The region becomes a venue for the fest of amateur song named "Pervotsvet" and the festival of bard song "Azish-tau". The Karachay-Cherkess Republic. Currently the tourist areas of the Republic are the most popular ones for weekend breaks among the population of the North Caucasus region. There are such ski resorts as Dombai and Arkhiz. The average altitude of the mountains is about 3-4 thousand meters and this means the resorts are located in highlands with all year round snowpack and partially glaciated slopes.

The bigger part of the Caucasus state wildlife biosphere reserve named after Kh.G. Shaposhnikov is located in the region. This is the largest and the oldest specially protected natural area in the North Caucasus. Many types of endemic plants and animals are represented there. There is also an artificially rebred species of Caucasus wisent that was killed off in the early 2oth century (Ataev \& Bratkov, 2011). The region is famous for the opportunities for alpine climbing since 1894. The national mountaineering competitions are held there. The great variety of natural resources promotes ecotourism development. Unique ethnic and subethnic indigenous groups create opportunities for ethnographic and cultural tourism. Hiking routes of the region also attract many tourists each year. The most popular one is №25 developed in Soviet times. It goes from Arkhyz to Krasnaya Polyana, Adler and Ritsa Lake in Abkhazia (Starostenko, 2011).

Unorganized camping starts to gain popularity again. According to surveys organized by researchers from the North Caucasus Federal University in 2013, the main reference group for this type of activity are the dwellers of Russian largest city regions of Moscow and Saint-Petersburg. The most famous destinations are the Gonachkhir, Makhar, Alibek and Amnauz gorges. The lack of tourist infrastructure as well as internet and cell phone signal coverage are the main factors determining the choice of destination for resting from everyday life. That is the reason of keeping such places in the North Caucasus. The biggest resort of the republic is the village Dombai. A group of academics of the Saint Petersburg Research Institute led off its development in 1930s. Nowadays there are 93 hotels per square kilometer. Two luxury apartment complexes "Sputnik" (Moscow) and "Krokus Invest" (Stavropol) are in process of construction. Simultaneous capacity of all these buildings is 4500 persons including village residents. If we also take into account holiday visitors, the population density of Dombay Meadow will come to 10000 people $/ \mathrm{km}^{2}$. One of the aspects for tourism development in the region is unique climate resources of Teberda resort. On «The list of Russian resorts including reasoning their unique natural therapeutic factors» approved by the Ministry of Public Health of the Russian Federation Teberda resort is under № 1.4 out of 18. It is reasoned as "especially beneficial for active pulmonary tuberculosis treatment".

The official recognition of the area was preceded by empirical studies and experience accumulation, which proved the beneficial features of the local climate. Nowadays there is a tuberculosis sanatorium with 350 bed spaces. The Kabardino-Balkar Republic. During the Soviet times different ethnoses of Abkhazo-Adyghean language group (the Circassians or the Adyghe), the Kabardians, the Balkars (a Turkic people) formed the population of the region. Cultural diversity of all these ethnic groups is a basis for unique cultural heritage of the region. Syncretic traditions and customs established sustainable anthropogenic system that has just started forming, but at the same time is a 
reason for multiple interethnic conflicts affecting the tourism development in the region (Matveeva \& Savin, 2011). Nevertheless, due to Elbrus (the highest mountain in Europe) location in the Republic it attracts about 260 thousand tourists annually. Ski resort and vast opportunities for mountain climbing make this place good for various types of tourists. Lately the adventure sports like hang-gliding and paragliding gain increasing popularity. One of the reason is a unique mountain hang-gliding and paragliding center Cheghem located on the border with Georgia on Zinka mountain sides. Its peculiar feature is combination of weather conditions of diverse complexity within $3-5$ meters from take-off. Now this place is a venue for various national sports events (Baragunova \& Kaloeva, 2014). The heritage of the Soviet times includes sanatoria.

The main city Nalchik is a balneo-mud and climatic health resort. There are more than 10 springs of mineral water in this city. The Republic of North Ossetia-Alania is an area of indigenous Caucasian people - the Ossetians. Despite the accession to the Russian Empire in the $18^{\text {th }}$ century, this Republic has kept its national and cultural identity and is one of the regions in the North Caucasus that almost avoided integration. The most obvious example is religious views of the local population. The highest percentage of pagans (29\%) in the Russian Federation lives in this region. Thus, neither Christianity, nor Islam could not became the official religion of the area. The main types of tourism in the region are cultural, natural and ecotourism, which are usually combined in mixed tours. Natural heritage of the area includes beautiful mountain gorges - the Tseyskoye, the Fiagdonskoye, the Karmadonskoye and the Dargavskoye ones and unique deep karst lakes (Kurskiev, 2012). There are also springs of sulphide, sodium-chloride and thermal carbon types of water as well as therapeutic mud sources, but they are underused (Isachenko \& Chizhova, 2012).

Cultural heritage of the republic includes:

- necropoleis - semi-underground and underground stone crypts and family vaults ( $14^{\text {th }}-18^{\text {th }}$ centuries) located in blocks and related to cult of dead ancestors honored by the locals until the present;

- ancestral towers as the prevailing type of cultural monuments. The towers are located almost in each village in mountain are of the region.

One of the mains factors for tourism development in the region is Kazbek mountain (5033 meters), one of the most splendid and lofty European mountains. Kazbek is located at the boarder between Russia and Georgia, but the most challenging climbing route threads along the northern (Russian) slopes. The routes to the summit are a good example of integration of tourist heritage of all the regions of the North Caucasus region.

The Republic of Dagestan is located in the north-east of the Caucasus along the Caspian Sea coast. In world history this area is known as "Albania" or "Caucasian Albania". This is the most multiethnic region of the Russian Federation. Peoples of Dagestan speaks languages that belong to 4 main linguistic groups. Uniqueness of cultural heritage creates inimitative local flavour that is one of a kind on the Earth.

Among the main tourism activities offered by this region are:

- resort therapy and beach-related rest at the seaside. There are such balnearies as "Talghi” (uses sulphide high concentrated water containing hydrogen sulphide), «Kayakent» (hydrothermal therapeutic muds), «Caspiy» (thermal and mineral water), «Akhty» (mineral water from five alkaline saline springs) (Dzhamaludinova, 2013);

- Islamic religious pilgrimage. There is one of the main natural Islamic sacred places in the region - Shalbuzdag mountain. The sphere of religious tourism that serves tourist from other Russian regions, Middle Asia and East grows rapidly over recent years. There are also the oldest mosques in the world - Dzhuma Mosque in Derbent, Central Dzhuma Mosque in Makhachkala, Karakure Mosque and others (Alexseev, 2009); 
- mountain and ecological tourism. The region offers a vast diversity of natural resources for alpinism, trekking, rafting and camping. The Karadakh gorge, Khala-Khelyi and Kazenoy-Am lakes, Bogosskiy, Nukatlsky, Butnushuer - Korkagel ranges are one of a kind because of their beauty and splendor;

- cultural tourism. There are such ancient cultural monument as Derbent - the oldest "gates of the Caucasus" and Naryn-kala fortress; Midzhakh village - the Museum of the Lezgians; Makhachkala - the largest cultural center of the Dagestan peoples; Gunib village - the essential place of the Caucasian War, ancient Persian baths, etc.

The Republic of Ingushetia. This is the smallest region of the Russian Federation. It is located on the northern sides of the Greater Caucasus and the adjoining smaller mountain chains - the Terek Range, the Sunja Range and the Skalisty Range. The area of the region is historical habitat of indigenous Caucasian people named Ghalghai or the Ingush (Yampolskaya \& Ivanov, 2015). Nowadays tourism development in the region is considered to be a promising project for future decades. In many ways, the reason is geopolitical uncertainty and activity of political Islamic groups that prevent pro-Russia trends among the Ingush people. On the one hand, this leads to relative "underdevelopment" of regional recreation sphere. On the other hand, it promote conservation of local natural heritage as opposite to popular North Caucasus resorts (such as those in the Karachay-Cherkess Republic). Thus, saying about lack of organized tourist flows to the Republic it is necessary to highlight the following promising groups of resources important for tourism development:

- natural heritage. This includes the area of Dzhejrakhsko-Assinsky State Historical, Architectural and Natural Open-air Museum, beautiful mountain gorges (Dzheirakh, Galgaiche, Armkhi, Guloi-Khi and Targimskoy hollow), waterfalls (Lyazgghisky and Furtougsky), holy Mat-Loam (Stolovaya) mountain and others;

- ski resorts. Currently there is only one open recreational resort named Armkhi situated on the northern and southern sides of the Skalisty Range. The complex includes two hotels, a cable railway, a cycle route, a swimming pool and an adventure park;

- cultural heritage. Among this kind of resources the first place belongs to the ruins of medieval towns and towers (Vovnushky, Erzi, Furtoug, Anghety, Magoi-Dzhel, Gul, Verkhny Pui, Kyazi, Lyalakh, Khani, etc.) There is also the oldest church in the Russian Federation built in the $18^{\text {th }}$ century - Tkhaba Erdy.

The largest regional cities of Magas and Nazran also attract tourist attention, but the lack of tourist infrastructure reduces it to some isolated cases. Annual number of tourists arriving to the Republic does not exceed 2000 people (The North Caucasus: The Challenges of Integration, 19 October 2012). The Chechen Republic. The region is located in the east of the North Caucasus in the Terek and Sunzha rivers valleys. This is a habitat of indigenous Chechen people. Among the Russians, this republic is mainly connected with the Caucasian wars, the first and the second Chechen wars. This fact has unfavorable impact on tourist and recreational image of the region. Nevertheless, over recent years the tourist flows to this area increases. Largely the reason is the policy of Ramzan Kadyrov, the head of the Republic. Large investments and public outreach in the region promote both tourist infrastructure development and relation to tourism as a main source of income for local (Matveeva, Savin, 2012). The following groups of tourist resources of the region can become a base for sustainable tourism development in the region:

- monuments of natural and cultural heritage located in Argun State Architectural and Natural Reserve Museum (150 towers, more than 20 religious buildings, more than 200 military towers of Early Middle-Ages, 150 ruins of castles and fortresses, dozens of megalithic ruins, 2600 ruins of ancient military and guard towers, about 150 underground and aboveground crypts) (Betilgiriev \& Gayrbekov, 2011); 
- modern ethnographic and ethno-confessional monuments. These include the Akhmad Kadyrov Mosque named "The Heart of Chechnya" in Grozny, Dondi-Yurt museum complex - reconstructed medieval Chechen village in Urus-Martan and one of the largest medieval necropolis in the Caucasian region named «Tsoi Pede", an elaborate cemetery in the Malkhistin gorge;

- balneological resources. There are outlets of Sulphur springs in the region. In Soviet times there was nation-wide spa resort. In 2014 the resort was reopened in Sernovodskaya village.

\section{FACTS AND FIGURES}

Now that we have seen all the qualitative characteristics of the tourist potential capacity of the North Caucasus, let us study the qualitative indicators. Despite the rich natural and cultural heritage of this area, such important indices as the level of social and economic development and standard of living in the regions under research are the lowest ones among the all 85 territorial entities of the Russian Federation.

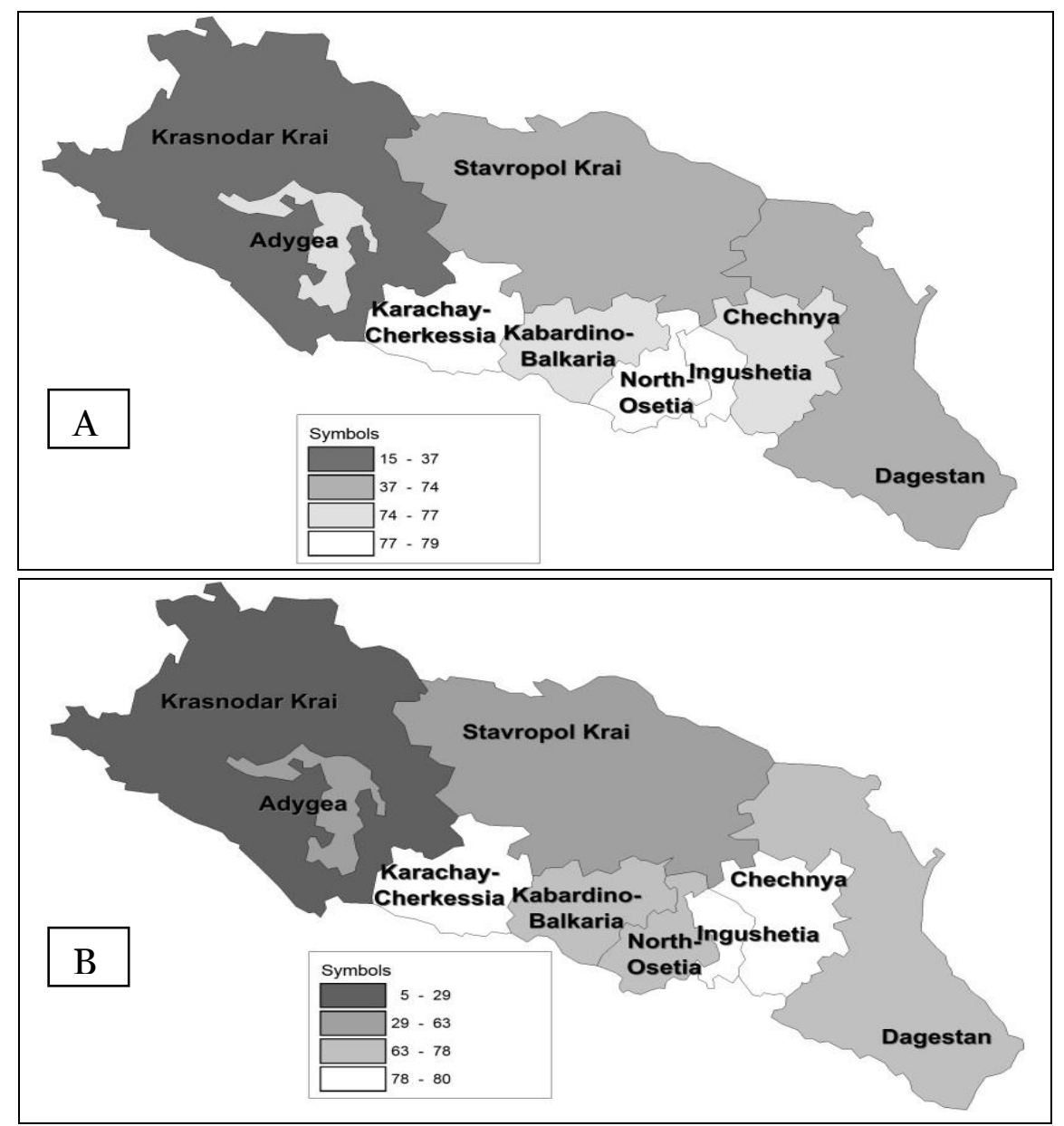

Figure 2. The main indicators of the development level of North Caucasus regions:

A) the level of social and economic development of a region; B) standard of living

(Source: RIA rating (RiaRating) and national rating (National tourist rating), 7 December 2015) 
This is supported by the data of independent sociologic agencies like RIA rating (RiaRating) and national rating (National tourist rating, 7 December 2015) (Figure 2). All the regions on the schematic map are ranked by the four main indicators of standard of living and level of economic development. The lowest value gets the highest position in the rating and those with the highest values are the most underdeveloped regions of the country. According to the map the most favorable conditions are in Krasnodar Krai, while the Karachay-Cherkess Republic, the most promising region for tourism development, is ranked very low. Occupancy rate of the main region resorts clearly demonstrates season dynamics of tourist resources demand. Despite of great variety of tourism types winter sports (ski, snowboard, toboggan) are the leading one. Today the biggest occupancy rate among all the regions falls on a winter season - the season of winter sports that lasts from January till March. Its rate in summer comes to 10-20\%. Spring and autumn are off-seasons, except the short period of autumn and spring school one-week breaks. That is the reason of low profitability, the problem of which is being solved by high prices. Costs for one room per night float between 1.5 and 3.0 thousand roubles in winter. Winter vacation that lasts 10 days will cost about 50-80 thousand roubles, which present the similar rate to the foreign tour costs while the service grade stays low. During the Soviet Union period the quality service factor was one-to-one, which means that one service unit was fixed for one visitor. No changes have taken place since then. The European standard differs and is equal to the rate of 1 to 5 or even 1 to 7 . To gain the same quality level of service staff increase up to 15-20 thousand workers as well as creation of new hotel facilities are to be done.

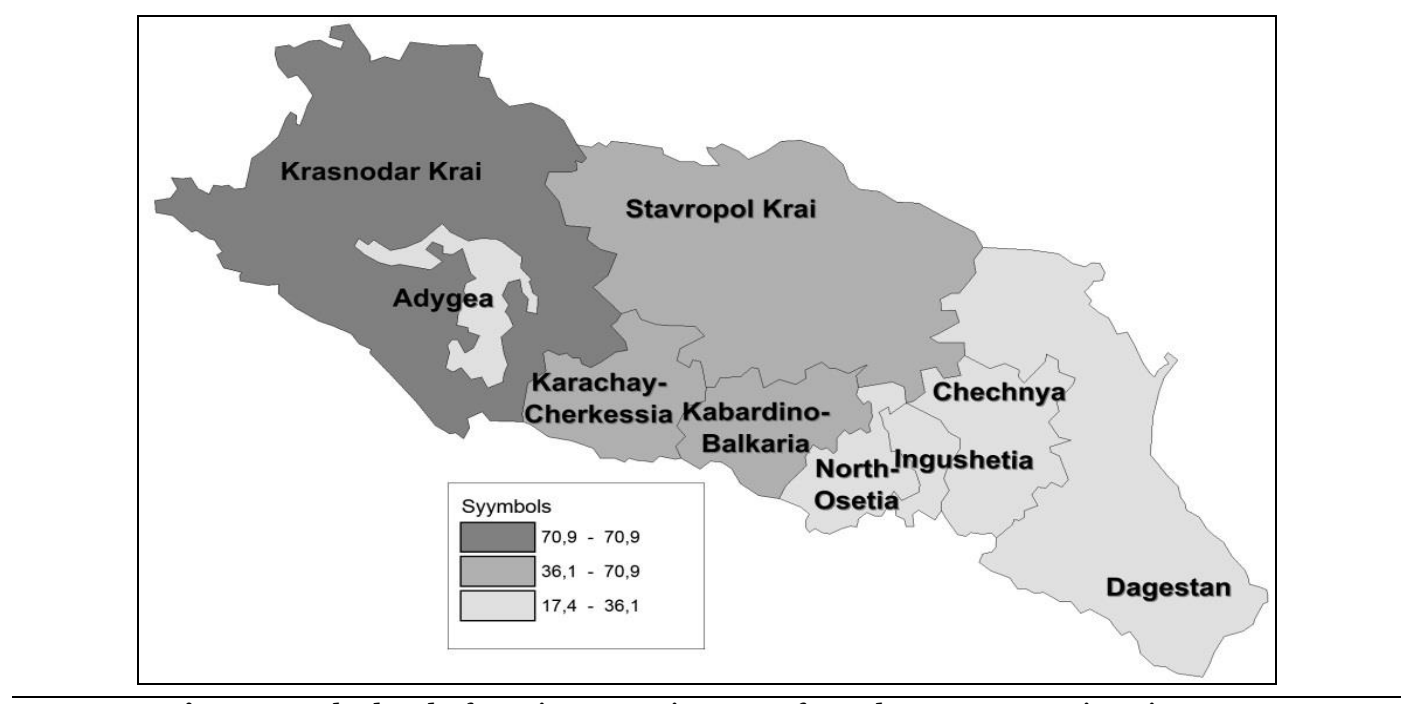

Figure 3. The level of tourist attractiveness of North Caucasus regions in 2015

(Source: National tourist rating, 07. 12. 2015)

Another important indicator is tourist attractiveness. It includes the level of tourist business development, income from tourist services, popularity of the region among Russians and foreigners, environmental setting and many other factors (National tourist rating, 7 December 2015) (Figure 3). As a result, Krasnodar Krai the most tourist attractive region in the North Caucasus. The eastern regions and the Republic of Adygeya are much less attractive. Thus, when analyzing the current 
condition of tourist and recreative industry of the North Caucasus, one should also consider such independent data despite the information on tourism in the region found in Internet speaks for positive results in regional tourism development.

\section{PROSPECTS OF TOURISM DEVELOPMENT IN THE NORTH CAUCASUS}

The Strategy of social and economic development of North Caucasus federal district up to 2025 involves development of tourist cluster in the region (Identification summary of the state program of the Russian Federation "Development of North Caucasian Federal District" up to 2025). Thus, in 2010 joint stock company "Resorts of the North Caucasus» was established by the decree of the Russian Government. It operates on the principles of public and private partnership as a managing company for this project. As a part of the project the agreements on establishing special economic zones in the Russian regions included in tourist cluster were issued (Project of tourist cluster managed by stock company «Resorts of the North Caucasus», 2014). Thus, 7 special tourist economic zones in Southern and North Caucasus Federal Districts were created. The following resorts are currently under construction: Arkhyz - in the Karachay-Cherkess Republic, Mamison - in the Republic of North Ossetia-Alania, Elbrus-Bezenghi - in the Kabardino-Balkar Republic, Armkhi and Tsori - in Dagestan, Lagonaki - in Krasnodar Krai and the Republic of Adygeya (Concept of tourism cluster development in the North Caucasus Federal District, Krasnodar Krai and the Republic of Adygeya, Moscow, 2011).

№1. "Arkhyz" year-round tourism and recreation complex. This point of the tourist cluster is located in Zelenchuk area of the Karachay-Cherkess Republic. One of the longest cable-railways at Russian ski resorts is constructed in Arkhyz complex. The gondola lift equipped with 8-seat gondolas carries 2400 persons per hour. A chairlift and a cable-railway for children also operates there. The slopes are equipped with systems of artificial snowing and illumination. Since season 2015/2016 after one more cable-railway and three ski trails were put into operation the capacity of all lifts in Arkhyz complex has reached 6600 persons per hour, the length of trails is about 14,5 $\mathrm{km}$. Long-term Arkhyz complex development program includes building five tourist villages. In addition to the existing "Romatik" village "Lunnaya Polyana", "Pkhia", "Dukka" and "Dukka-200o" will be built. All of them will be connected by the common infrastructure and tourist offer designed for all types of tourists. According to the development program, Arkhyz will include 58 lifts and 137 ski trails of diverse complexity (Shebzukhova et al., 2014). 60\% of them will be green and blue trails for beginners. The volume of estimated tourist flow by 2020 is 445 thousand people.

№2. "Elbrus-Bezenghi" year-round tourism and recreation complex. The complex is planned to be built on the territories of Chereksky, Chegemsky, Zolsky and Elbrus areas of the Kabardino-Balkar Republic. Modernization of the resort was started in 2014. The first efforts in ski trails renovation for season 2014-2015 resulted in steep increase of tourist flow. In winter season 2014-2015 140 thousand ski passes were sold. It is more than throughout 2014. According to the survey conducted by JSC "KSK" among the tourists of the Elbrus resorts, 94\% of respondents would like to come back next year.

One million rubles was allocated in 2015 for the resort modernization. This money was used for the third funicular line construction. Elbrus cable railway will be the most high-altitude and will bring people to the highest European ski resort. It will also be equipped according to the needs of disable people. №3. "Veduchi" year-round tourism and recreation complex. This complex is located in Itum-Kalinsky area of the Chechen Republic, in the Argun River valley. One of the problems of Veduchi construction was bombs left in this area after the war. Within the first six months of 2010 the sappers have cleared up 200 ha. For now 500 ha more are demined. The program involves construction 
of 19 trails of total length equal to $32 \mathrm{~km} ; 8$ cable railways (one of them is child lift, a lift for children training); hotel complex for 500 persons, servicemen's living accommodation, chalet village, service facilities including ski training center, rental centers, restaurants and cafes. The final planned capacity of the resort will be 4,8 thousand persons per day. One of the features of Veduchi resort will be the most long trails for 12,5 km. Due to it the resort will achieve top-10 best European resorts with the longest ski trails. №4. "Mamison" year-round tourism and recreation complex. The resort locates in the Mamison gorge in the Republic of North Ossetia-Alania. Mamison is situated $102 \mathrm{~km}$ from Vladikavkaz international airport and $85 \mathrm{~km}$ from Vladikavkaz railway station. The resort area is more than 84 thousand ha. The surface area of the slopes is up to $19,5 \mathrm{mln}^{2}$. The elevation change is 2042-4038 meters above sea level.

Mamison resort is able to change economic situation in the region. The main problem of land use planning and management there is landscape and total absence of tourist infrastructure. Its uniqueness lies in quantity and quality of natural mountain trails, a rather rare phenomenon in the rest of the world. Such natural trails remain open longer due to glaciers. They can prolong ski season up to 2 months. Zaramag glacier can keep trails open even in summer. №5. "Tsori and Armkhi" Year-round tourism and recreation complex. Armkhi resort locates in Dzheyrakhsky and Sunzhensky areas of the Republic of Ingushetia, on the Skalisty and Tsei-Loamsky Ranges According to the program 4 trails of total length equal to $11 \mathrm{~km}$ and 4 lifts will be built there. Armkhi locates on the south and north sides of the Skalisty Range, its maximal altitude is $3 \mathrm{~km}$. Currently the elevation change is $300 \mathrm{~m}$, by the end of construction it will be equal to 1,5 $\mathrm{km}$. The key element of the resort is Tsori ski complex. Approximately, in 10 years it should reach its European competitors (Italian, Austrian and Swiss resorts) by the level of equipment and variety of tourist services. The plan is to build there $57,4 \mathrm{~km}$ of trails, 12 lifts, a ski and biathlon center including a shooting zone and a stadium, an extreme park and an ice palace. Between the two resorts, at an altitude of 1700 meters an 18-hectare golf course will be constructed. All the neighboring airports and railway stations will be renovated and enlarged. The distance between the resorts is $45 \mathrm{~km}$. There is an asphalt road for $10 \mathrm{~km}, 20 \mathrm{~km}$ of gravel road and $15 \mathrm{~km}$ more are under construction.

№6. "Lago-Naki" year-round tourism and recreation complex. This ski resort will be built on the Lagonaksky highland, a part of the Western Caucasus located in the Apsheron area of Krasnodar Krai and the Republic of Adygeya. The program of mountain climate resort development consists of 2 parts: winter adventure sports and tourism; tourism in off-season time and in summer. The key idea of the ski resort construction project is a theme park with sections for different types of visitors. Each of these sections will offers some specific activities: ski trails, snowboard park (including freeride trails for athlete training, competitions and other sport events), ski trails for children, toboggan area, paths for snowshoeing, skating and curling rink. Implementation of the first project stage is planned for 2013-2019. The targeted capacity of the resort after the first building phase completion is 7000 persons including hotel complex for 1 thousand persons. The infrastructure of the first phase will comprise 14 funiculars and 35 ski trails of the total length equal to $50 \mathrm{~km}$. The resort will create 2 thousand jobs in tourist infrastructure. In total 4 thousand people will be employed. №7. "Matlas" yearround tourism and recreation complex. The resort is located in the Khunzakh area in Dagestan, $180 \mathrm{~km}$ from Makhachkala international airport (Erkenova, 2015).

There is a new airdrome for regional and private flights $10 \mathrm{~km}$ from the resort. Investing in the resort is considered to be a priority for the near future. The resort will become a base for an ethnic and nature museum, a ski center. The resort capacity will be 18500 persons per day. After the first building phase is completed the capacity of tourist 
accommodation establishments will be 6800 persons. The plan is to construct 25 ski trails of various complexity. Moreover, Matlas has strong balneological potential. There are dozens of mineral springs. This water is beneficial for kidney disease and intestine issue treatment. Finally the most important but almost unstudied type of tourism in the region is wildlife tourism or hiking. At the present time the only agency that control this activity is border-security forces. The number of wildlife tourists only in the The KarachayCherkess Republic runs up to 100-200 thousand people per year.

The research conducted at the valleys of the rivers Sofia and Adzapsh produced amusing results. Daily amount of visitors of the river Sofia valley (nearby the Arkhyz) going camping in July and August comes up to 700-800 people, at some particular days even up to 1000. This leads to total amount during the season equals to 20-25 thousand tourists. The most popular activity among them is ecotourism (wellness or health tourism, sport and excursion tourism). There are springs of different kinds of mineral water in valley of the river Adzapsh, which is $15 \mathrm{~km}$ away from the last village Phiya. The main branch of health tourism is arthropathy treatment. Mineral baths are made at the place of adarce in the open air. The temperature of mineral water is 18 degrees. There is a number of springs that serves to specific treatment, such as eyes cure, gastrotherapy, hemorrhoid therapy, etc. There is also sacred spring that is used for alternative medicine. About 10 thousand people come during a season to visit this place. As a rule, they live in tents with all the conveniences outside, which causes unfavorable environment conditions. Standards of environmental safety are missing. For such a big group of tourists a set of arrangements is to be done, among which development of camping area with minimal set of paid services. This will help to follow sanitation measures and save headstreams of Kuban' rivers, which represent the main source of water for human consumption in Pre-Caucasian Region.

\section{CONCLUSION}

As the result of our analysis, we should note reach natural and cultural heritage of the North Caucasian region that can form a unique offer on the world tourist market. Nevertheless, the existing unsolved problems lead to low internal demand and adverse demand on the international tourist market. Among such problems are:

- lack of tourist infrastructure in many regions where unique tourist attractions locate. Significant funds are allocated for these needs from the federal budget, but corruption at all the levels of government prevents appropriate use of this money;

- language and cultural barrier is one of the main obstacles for tourism development. The majority of population considers ethnic identity and usual mode of life to be more important than laws of hospitality necessary for creating reputation of any resort. Ignorance of English (in some cases even of Russian) among the locals creates more obstacles for foreign tourists arriving to the North Caucasus;

- managerial imbalance in designing region development strategies. In most cases, they are developed by the national government and sent to the regions. The problem is that the Government has no actual data on the current situation in these regions. That leads to "detachment" of region development strategies from real life;

- modern geopolitical situation: location of the North Caucasian region on the borders between Russia, Abkhazia, South Ossetia and Georgia and Azerbaijan. For now, it does not create any real geopolitical threat, but there is still a shadow of the Chechen wars, the Ossetian conflict and other incidents of the $20^{\text {th }}$ and $21^{\text {st }}$ centuries.

Solving these urgent problems together with implementation of the Development Strategies will result in better living of the local population and will make the North Caucasus an attractive resort for both Russian and international tourists. 


\section{REFERENCES}

Aleksandrov, V. V., \& Gevondyan, A. V. (2015). Role of the state corporate sector in financial development of travel industry of the North Caucasus Federal District. Fundamental researches. № 2 (part 13), 2871-2875.

Alexseev, M. A. (2009). The Impact of the Hajj Pilgrimage in the North Caucasus. Eurasia Policy Memo. № 74 San Diego State University.

Ataev, Z. V., \& Bratkov, V. V. (2011). Representation of the net of protected nature areas to the landscape diversity of the North Caucasus. Relevant issues of humanitarian and life sciences. № 10, 272-276.

Baragunova, L. V., \& Kaloeva Z. Yu. (2014). Prospects of tourism development in the Kabardino-Balkar Republic, №8 (12), 544-547, JSRP.

Betilgiriev, M. A., \& Gayrbekov, M. S. (2011). SWOT-analysis and strategic priorities of tourism development in the Chechen Republic. Economic space. № 4-3, 192-196.

Dzhamaludinova, N. M. (2013). Organisational and economic aspects of Seaside-Mountain type of tourism development in the Republic of Dagestan. Strategy of sustainable regional development in Russia. № $16,97-103$.

Erkenova, M. M. (2015). Tourism development in the Nortn Caucasus region under conditions of economic crisis. Economics and management in $21^{\text {st }}$ century: development trends. № 23, 46 -50.

Isachenko, T. E., \& Chizhova, V. P. (2012). Transformation of natural and cultural complexes of mountainous regions in the $20^{\text {th }}$ and $21^{\text {st }}$ centuries. The case of Alania national reservation. Issue $3,91-103$, Bulletin of the St. Petersburg University. Series 7: Geology, Geography.

Kurskiev, T. G. (2012). Potential of sustainable tourism development in the Republic of North Ossetia, № 47 (11), UekS.

Matveeva, A., \& Savin, I. (2012). North Caucasus: views from within. People's Perspectives on Peace and Security. P. 15-19, Saferworld, London, United Kingdom.

Melvin, N. (2007). Building Stability in the North Caucasus: ways forward for Russia, P. 38, Neil J. Melvin Solna: SIPRI.

Polyakova, A. V. (2015). Features of ethnographic tourism development in Stavropol Krai. Science, engineering and education. № 7 (13), 79-80,

Shadova, Z., Tappaskhanova, E., Abrhám, J., \& Zumakulova, Z. (2015). Tourism security and sustainability: a case study of north Caucasus region. Journal of Security and Sustainability. Issues 4 (3), 509-519,

Shebzukhova, T. A., Kiseleva, N. N., \& Sankin, A. V. (2014). Development of tourist cluster in North Caucasian Federal District. Service plus. № 1, $101-107$.

Starostenko, K. V. (2011). Development of adventure tourism in Russia: issues and prospects. Central Russian Bulletin of Humanitarian Sciences. № 2, 183-186, Orel.

Yampolskaya, D. Yu., \& Ivanov, S. A. (2015). National identity of the peoples of the North Caucasus: issues and prospects. Modern science: relevant problems and way of solution. № 3 (16), 194-197.

*** Identification summary of the state program of the Russian Federation "Development of North Caucasian Federal District" up to 2025, (2016).

*** Concept of tourism cluster development in the North Caucasus Federal District. Krasnodar Krai and the Republic of Adygeya, (2011), Moscow.

*** GPF - Geopolitical Futures, (2017) https://geopoliticalfutures.com/north-caucasus-russias-southernbuffer/_2017.

*** National tourist rating (№1), (2015), 07.12.2015.

*** Project of tourist cluster managed by stock company «Resorts of the North Caucasus», (2014). http://www.ncrc.ru/investproekty/.

*** RiaRating - national rating agency, (2014), http://vid1.rian.ru/ig/ratings/life_2014.pdf.

*** The North Caucasus: The Challenges of Integration (I), (2012), Ethnicity and Conflict Crisis Group Europe Report № 220, 19.10.2012.

*** Too Far, Too Fast: Sochi. (2014). Tourism and Conflict in the Caucasus Europe Report № 228, 30.01.2014.

Submitted:

20.12.2017
Revised:

11.05.2018
Accepted and published online 15.05.2018 